\title{
From the History of Russian Hymnography of the Modern Period: the liturgical works of hieromonk Dimitry (Voskresensky)
}

\section{V. Sidneva ${ }^{1}$}

${ }^{1}$ Lomonosov Moscow State University, GSP-1 Leninskie Gory, Moscow 119991, Russian Federation

DOI: $10.18255 / 1996-5648-2021-3-360-369$

Research article Full text in Russian

The paper examines the hymnography of hieromonk Dimitry (Voskresensky) (1871-after 1919) in the context of the rise of interest in Russian holiness in the Russian Orthodox Church and society in the middle of the 19th - early 20th centuries. The popularization of veneration of Russian saints is realized by hieromonk Dimitry on two levels: the creation of liturgical texts and the publication of historical essays about the holy places of Russia and the biographies of ancient and new Russian ascetics.

Keywords: hieromonk Dimitry (Voskresensky); the Orthodox hymnography; Russian holiness; service; akathist

\section{INFORMATION ABOUT AUTHORS}

\begin{tabular}{l|l} 
Sidneva, Maria V. & $\begin{array}{l}\text { E-mail: marysidneva@gmail.com } \\
\text { Postgraduate }\end{array}$
\end{tabular} 


\title{
Из истории русской гимнографии \\ Нового времени: литургическое \\ творчество иеромонаха \\ Димитрия (Воскресенского)
}

\author{
М. В. Сиднева ${ }^{1}$
}

${ }^{1}$ Московский государственный университет им. М. В. Ломоносова, Ленинские горы, д. 1, Москва, 119991, Российская Федерация

DOI: 10.18255/1996-5648-2021-3-360-369

УДК 94(47)+271.22(470+571)

Научная статья

В статье рассматривается неизвестное гимнографическое наследие иеромонаха Димитрия (Воскресенского) (1871- ум. после 1919 г.) в контексте подъема интереса к русской святости в Русской церкви и обществе в середине XIX - начале XX века. Популяризация почитания русских святых осуществляется иеромонахом Димитрием на двух уровнях: создании богослужебных текстов и издании исторических очерков святых мест России и жизнеописаний древних и новых русских подвижников.

Ключевые слова: иеромонах Димитрий (Воскресенский); православная гимнография; русская святость; служба; акафист

ИНФОРМАЦИЯ ОБ АВТОРАХ

Сиднева, Мария Владимировна $\mid$ E-mail: marysidneva@gmail.com

Аспирант

В январе 1912 г. в «Русском иноке» было опубликовано «Открытое письмо». Автор, скорбя о небрежении, наблюдаемом в русских храмах и обителях к почитанию памяти русских святых, предлагал заменить многие службы «Святых Восточных Церквей службами родственных нам угодников Божиих» [1, с. 41] с тем, чтобы неукоснительно совершалось должное празднование.

Идея пересмотра состава служебных миней была не нова. Последнее десятилетие XIX века ознаменовалось включением в служебные минеи нескольких последований русским святым. В 1909 г. в свет вышла «Дополнительная Минея» с 13 службами русским святым [2]. Расширение состава миней происходило на фроне подъема общественного интереса к русской 
Сиднева М. В.

святости, нашедшего отражение в беспрецедентном для Синодального периода количестве торжественных канонизаций в правление Николая II, изучении, переводе на русский язык и издании памятников отечественной агиографии, составлении уникального «Верного месяцеслова русских святых» архиепископа Сергия (Спасского) [3], а также попытках восстановления празднования дня памяти всех Русских святых [4].

«Открытое письмо», послужившее откликом на прославление в 1911 г. свт. Иоасафа Белгородского, было написано послушником Алексеем Воскресенским, впоследствии иеромонахом Димитрием, личным почетным гражданином, активным церковным публицистом, историком и путешественником. Это имя малоизвестно для исследователей, хотя ему и посвящено несколько обзорных статей [5-6].

Алексей Константинович Воскресенский родился в 1871 г. в семье бедного псаломщика, закончил Нижегородское духовное училище и 12-летним отроком вступил послушником в одну из обителей родного Нижегородского края. Незадолго до революции Алексей Воскресенский после 33 лет послушничества и перехода по разным монастырям принял постриг в Оренбургском Успенско-Макарьевском монастыре с именем Димитрия, а накануне революции он стал иеродиаконом, а вскоре и иеромонахом.

Революцию и Гражданскую войну иеромонах Димитрий пережил на Нижегородской земле; последним известным его местопребыванием стал Оранский Богородице-Рождественский монастырь. После 1919 г. следы иеромонаха Димитрия теряются.

По его собственному признанию, сильнейшим впечатлением детства, определившим во многом его дальнейшую судьбу, стало чтение Четьихминей свт. Димитрия Ростовского и встреча в монастыре с иеромонахом, путешествовавшим по России и Востоку. «..Под его руководством в душе юного послушника родилась ненасытимая страсть к чтению произведений преимущественно церковно-исторического характера и возникло стремление к путешествиям в прославленные места родной земли» [7, с. 4]. Сообразно этому стремлению Алексей Воскресенский посвятил свою жизнь путешествиям по России и написанию очерков о святых местах.

Литературной «специализацией» о. Димитрия стали историкостатистические описания русских монастырей и жизнеописания русских подвижников. Материалом для них служили как личные наблюдения, сделанные автором во время поездок, рассказы свидетелей, так и архивные документы. Литературный дебют послушника Алексея Воскресенского состоялся в 1888 г. на страницах Костромских епархиальных ведомостей серией статей об истории и насельниках Свято-Троицкой Кривоезерской пустыни Костромской губернии [8-14]. Впоследствии им были составлены исторические описания и других обителей Костромского края - Николаевского Бабаевского [15], Иоанно-Предтеченского Железно- 
боровского [16] и Свято-Троицкого женского монастыря Галичского уезда [17-20]. В ходе путешествия на юг России А. Воскресенский составил очерки истории Воскресенского Мамай-Маджарского монастыря Ставропольской епархии[21],Успенско-Николаевской Чуркинскойпустыни[22-23]иПокровоБолдинского монастыря Астраханской епархии [24-33], Владикавказского Свято-Троицкого монастыря [34], Второ-Афонского Успенского монастыря [35-37], Черноморской Екатерино-Лебяжской Николаевской пустыни Кубанской области [38] и ряда других монастырей. Наряду со своими статьями Алексей Воскресенский осуществлял публикации документов из монастырских архивов, где работал и изучал истории обителей $[16$, с. $99-$ $116 ; 39]$.

В 1911 г.на страницах елецкой газеты «Голос порядка» был опубликован опыт исторического очерка А. Воскресенского «Город Елец в его настоящем и прошлом» [40]. Свято-Троицкому Павло-Обнорскому монастырю Алексей Воскресенский посвятил около 40 публикаций. Пребывая в монастыре в качестве послушника, он стал свидетелем и опубликовал описание визита в обитель великой княгини Елизаветы Федоровны [41]. Кроме очерка истории обители, вышедшего отдельным изданием в 1914 г. [42], А. Воскресенский написал серию статей «Троицко-Павло-Обнорский патерик» для «Русского инока», в которых представлены жизнеописания как древних святых обители, так и подвижников, живших в недавние времена, среди них игумен Иоасафр (Тихонов) (ум. 1884 г.) [43], иеромонах Нафанаил (ум. 1901 г.) [44], архимандрит Агафангел (Воскресенский) (ум. 1907 г.) [29], иеромонах Сергий (Малевинский) (ум. 1912 г.) [45].

В 1915 г. в «Кормчем» публиковались статьи «Благодатные пастыри земли Русской XVIII-XIX столетий», посвященные белым священникам, прославившимся благочестивой жизнью в различных уголках Российской империи. Всего до революции иеромонахом Димитрием было опубликовано более 250 статей, целью которых были прославление и популяризация сведений о жизни древних, а особенно новых подвижников благочестия.

Другим аспектом трудов иером. Димитрия по прославлению русских святых было создание посвященных им богослужебных текстов. Вероятно, что начало гимнографического творчества положил случай, приведший бегущего от войны послушника А. Воскресенского в Тульскую губернию. В 1888 г. Святейший Синод восстановил почитание и дал официальное разрешение молитвенно прославлять преподобного Макария Жабынского [46, л. 1], в 1898 г. тульский протоиерей А. Иванов составил канон святому, который включался в состав общей службы преподобному при совершении бдения святому Макарию [46, л. 6-8 об.]. В 1914 г. Жабынский монастырь готовился отмечать 300-летний юбилей возрождения обители после разорения поляками, в связи с этим настоятель монастыря игумен Кирилл поручил 
Сиднева М. В.

послушнику Алексею Воскресенскому, который некоторое время пребывал в обители, довершить службу преподобному Макарию. Написанная служба была одобрена Санкт-Петербургским духовным цензурным комитетом и выпущена отдельным изданием в 1915 г. [47]. Впоследствии эта служба была включена в «Зеленые» минеи и вошла в современный богослужебный обиход. Что касается акафиста, как видно из документов, текст гимна также отправлялся в духовную цензуру, тем не менее отправляя экземпляры службы и цензурное разрешение отцу Димитрию в 1916 г., игумен Кирилл ничего не говорит об акафисте, который офрициального дозволения к печати по неизвестным причинам не получил [48, л. 99].

Иеромонах Димитрий, будучи ревностным почитателем святителя Димитрия и некоторое время насельником Ростовского СпасоЯковлевского монастыря, имел особое попечение о молитвенном прославлении Ростово-Ярославских святых. В одном из писем еп. Иосифу (Петровых) Угличскому он предлагает учредить отдельное празднование Ростовским святителям [48, л. 76]. Сохранились черновики службы и акафиста Ростовским Чудотворцам, созданные, очевидно, в надежде на установление празднования собора Ростовских святых [48, л. 7-8 об., л. 10-20].

В честь Ростово-Ярославских святых были написаны также два акафиста: святителю Игнатию Ростовскому [48, л. 9-9 об.] и преподобному Паисию Угличскому [48, л. 22-25], сохранившиеся в рукописях, также в письме еп. Иосифу упоминается акафист свт. Исаии Ростовскому [48, л. 75], текст которого утрачен. Небезынтересным является фракт, что сам епископ Иосиф известен как автор нескольких акафистов, среди которых акафист прп. Иакову Ростовскому, одобренный в 1913 году [49, л. 38, 39].

Еще одно место, к которому о. Димитрий имел особую привязанность, - это Вологодская земля. В Павло-Обнорском монастыре он долгое время пробыл послушником. Сохранилась рукопись службы с акафристом этому святому [50, л. 17-44], посланная о. Димитрием вместе со статьями для «Троицкого слова» Никону (Рождественскому) архиеп. Вологодскому, редактору журнала, в котором он публиковался с 1912 г. Ни служба, ни акафист, видимо, так и не были представлены в цензуру и не опубликованы.

Однако среди литургических текстов автора встречаются посвящения не только русским святым. Примером является служба преподобному Николаю игумену Студийскому [48, л. 53-56 об.]. Довольно необычный выбор святого обусловлен тем, что служба была написана для ярославского священника Николая Мирова, который, видимо, носил имя этого святого. Знакомство с о. Николаем, вероятно, произошло на почве сотрудничества в ярославском журнале «Приходская жизнь», редактором которого 
священник стал в 1915 г.; в последующие два года в журнале публикуется несколько статей иером. Димитрия, посвященных ростовским сюжетам. Служба заказчику понравилась, сохранилось письмо, в котором о. Николай благодарит за присыл службы и выражает желание получить одобрение в Синоде для ее публикации, чему, однако, не суждено было сбыться [48, л. 186-186 об., л. 194]. По-видимому, иеромонах Димитрий намеревался также составить акафист преподобному, сделав указание на него в службе, но текст либо не был написан, либо не сохранился.

Обстоятельства создания службы Пресвятой Богородице ради иконы «Троеручица» неясны. В черновике дошел только фррагмент утрени [48, л. 57-58 об.]. Известно, что дореволюционная минея не имела особой службы в честь Троеручицы, а присланная И. Морозовым в 1881 г. на рассмотрение в Московский духовный цензурный комитет служба с акафистом не была одобрена [51]. По-видимому, служба написана по личной инициативе иером. Димитрия и связана с его любовью к Афону.

Нетрудно заметить, что выбор посвящений обусловлен местами пребывания и путешествий иеромонаха Димитрия. Его гимнография создается для группы древних прославленных русских святых, которые имели преимущественно региональное почитание и не имели собственных служб. На протяжении XIX - в начале XX века отсутствие в минеях последования таковым святым постепенно восполнялось преимущественно путем одобрения и отдельного издания издавна употреблявшихся в определенном месте текстов или написания новых, чаще всего людыми, связанными с местом подвига или почитания святого. Bсе службы, написанные о. Димитрием, предполагают совершение всенощного бдения в день памяти этих святых, что предполагает их употребление в первую очередь в церквях и монастырях, связанных с особым почитанием святого. Хотя, вероятно, иером. Димитрий, создавая свои литургические тексты, надеялся способствовать тем самым всероссийскому почитанию избранных святых.

Характерно, что иером. Димитрий в равной степени работает как в жанрах, составляющих последование службы, так и в относительно поздно развившемся жанре акафиста, ставшем за XIX в. наиболее демократичным и популярным жанром в Русской церкви. Составление нормальногонаборалитургических текстов дляо.Димитрияподразумевает не только написание службы, но и акафиста, что свидетельствует об укоренении паралитургических акафистов в богослужебной практике Русской церкви.

В лице иером. Димитрия предстает замечательный пример «профессионального» гимнографа, для которого написание литургических текстов - не только выражение личного благочестия, но и своеобразная форма служения Церкви и народу. Интересна в данном случаеличностьсамогогимнографра,вчастностипроблема того,ктов Русской 
Сиднева М. В.

церкви Нового времени так или иначе воспринимает на себя эту роль. Прецедент обращения игумена Кирилла к послушнику-литератору для написания службы, выбор по критерию литературной одаренности и опыта указывает на близкую связь гимнографии и литературы в представлении людей эпохи. Это прослеживается и на влиянии русского литературного языка на церковнославянский новых акафристов и служб.

Таким образом, гимнографическое творчество иеромонаха Димитрия (Воскресенского) соответствует главным тенденциям церковной жизни своего времени. Преломление общих тенденций в индивидуальном творчестве всегда дает неповторимую единичную картину, а история жизни иеромонаха Димитрия добавляет замечательный штрих к коллективному портрету русских гимнографов Нового времени.

\section{Ссылки}

1. Воскресенский А. Открытое письмо Преподобным Аввам обителей, возлюбленнейшим отцам и братиям о Христе // Русский инок. 1912. № 2, вып. 50. С. 35-42.

2. Минея дополнительная. СПб.: С.-Петербургская Синодальная Типография, 1909. 153 л.

3. Верный Месяцеслов всех русских святых, чтимых молебнами и торжественными литургиями общецерковно и местно, составленный по донесениям Святейшему Синоду преосвященных всех епархий в 1901-1902 годах. М.: Синодальная Типография, 1903. 72 с.

4. Кравецкий А. Г., Плетнева А. А. Минейные службы Нового времени: история, поэтика, семантика // Минеи: образец гимнографической литературы и средство формирования мировоззрения православных. Olsztyn, 2013. С. 15-90.

5. Евдокимова А. А. Из неопубликованного наследия иеромонаха Димитрия - насельника Оранского Богородицкого монастыря // Наследие монастырской культуры. Ремесло, художество, искусство. СПб, 1997. Вып. 1. С. 5-11.

6. Власова Е. И. Религиозный писатель Алексей Константинович Воскресенский и его труды: открытие забытого имени // Здравница. 2012. № 29. URL: https://blagomm.ru/site/watchMagazine?id=14. № 30. URL: https://blagomm.ru/site/ watchMagazine?id=15. (дата обращения: 20.10. 2020).

7. Анатолий иером. Две годовщины из жизни скромного церковного писателя. Грязовец: Типография А. И. Краморева, 1912. 12 с.

8. Воскресенский А. «Житие и подвиги Преподобного и Богоносного отца нашего Тихона, Лухского Чудотворца» // Костромские Епархиальные Ведомости. Неофициальная часть. 1888. № 23. С. 646-654.

9. Воскресенский А. «Житие и подвиги Преподобного и Богоносного отца нашего Тихона, Лухского Чудотворца» // Костромские Епархиальные Ведомости. Неофициальная часть. 1888. № 24. С. 679-686. 
10. Воскресенский А. Свято-Троицкая Кривоезерская пустынь (Костромской губернии Макарьевского уезда) // Костромские Епархиальные Ведомости. Неофициальная часть. 1889. № 13/14. С. 276-284.

11. Воскресенский А. Свято-Троицкая Кривоезерская пустынь (Костромской губернии Макарьевского уезда) // Костромские Епархиальные Ведомости. Неофициальная часть. 1889. № 16. С. 317-327.

12. Воскресенский А. Чудотворная икона Иерусалимской Божией Матери, находящаяся в Троицкой Кривоезерской пуст. (Костромской губ. Макарьевского у.) // Костромские Епархиальные Ведомости. Неофициальная часть. 1889. № 10. C. 218-228.

13. Воскресенский А. Игум. Корнилий (Уланов) (в схиме Карион), изобразитель чудотворной иконы Иерусалимской Божией Матери (в Кривоезерской пуст.) // Костромские епархиальные ведомости. Неофициальная часть. 1889. № 6. С. 129-137.

14. Воскресенский А. Свято-Троицкая Кривоезерская пустынь (Костром. губ. Макарьев. уезда). Кострома: типо-лит. А. Азерского, 1904. 43 с.

15. Воскресенский А. Николаевский Бабаевский общежительный монастырь Костромской епархии и святыни его. Кострома: Губернская типография, 1912. 31 с.

16. Воскресенский А. Преподобный Иаков игумен, Железноборовский чудотворец, и основанный им Иоанно-Предтеченский Железноборовский монастырь Костромской епархии. Кострома: Губернская типография, 1913. 116 с.

17. Воскресенский А. Свято-Троицкий женский монастырь, Галичского у., Костромской епархии // Костромские епархиальные ведомости. Неофициальная часть. 1913. № 21. С. 609-624.

18. Воскресенский А. Свято-Троицкий женский монастырь, Галичского у., Костромской епархии // Костромские епархиальные ведомости. Неофициальная часть. 1914. № 3. С. 60-65.

19. Воскресенский А. Свято-Троицкий женский монастырь, Галичского у., Костромской епархии // Костромские епархиальные ведомости. Неофициальная часть. 1914. № 4. С. 82-87.

20. Воскресенский А. Свято-Троицкий женский монастырь, Галичского у., Костромской епархии // Костромские епархиальные ведомости. Неофициальная часть. 1914. № 6. С. 120-125.

21. Воскресенский А. Воскресенский Мамай-Маджарский монастырь Ставропольской епархии // Русский паломник. 1906. № 11. С 167-168.

22. Воскресенский А. Из современной летописи Чуркинской пустыни // Астраханские епархиальные ведомости. Неофициальный отдел. 1903. № 5. С. 221-224.

23. Воскресенский А. Святыни Успенской-Николаевской Чуркинской общежительной пустыни Астраханской епархии // Астраханские епархиальные ведомости. Неофициальный отдел. 1903. № 17. С. 890-896. 
Сиднева М. В.

24. Воскресенский А. Покрово-Болдинский монастырь близ Астрахани (Историко-статистический очерк) // Астраханские Епархиальные Ведомости. Неофициальный отдел. 1908. № 16. С. 605-615.

25. Воскресенский А. Покрово-Болдинский монастырь близ Астрахани (Историко-статистический очерк) // Астраханские Епархиальные Ведомости. Неофициальный отдел. 1908. № 17. С. 723-730.

26. Воскресенский А. Покрово-Болдинский монастырь близ Астрахани (Историко-статистический очерк) // Астраханские Епархиальные Ведомости. Неофициальный отдел. 1908. № 18. С. 683-692.

27. Воскресенский А. Покрово-Болдинский монастырь близ Астрахани (Историко-статистический очерк) // Астраханские Епархиальные Ведомости. Неофициальный отдел. 1908. № 22. С. 834-841.

28. Воскресенский А. Покрово-Болдинский монастырь близ Астрахани (Историко-статистический очерк) // Астраханские Епархиальные Ведомости. Неофициальный отдел. 1908. № 24. С. 909-915.

29. Воскресенский А. Покрово-Болдинский монастырь близ Астрахани (Историко-статистический очерк) // Астраханские Епархиальные Ведомости. Неофициальный отдел. 1909. № 2. С. 55-61.

30. Воскресенский А. Покрово-Болдинский монастырь близ Астрахани (Историко-статистический очерк) // Астраханские Епархиальные Ведомости. Неофициальный отдел. 1909. № 3. С. 91-102.

31. Воскресенский А. Покрово-Болдинский монастырь близ Астрахани (Историко-статистический очерк) // Астраханские Епархиальные Ведомости. Неофициальный отдел. 1909. № 4. С. 130-138.

32. Воскресенский А. Покрово-Болдинский монастырь близ Астрахани (Историко-статистический очерк) // Астраханские Епархиальные Ведомости. Неофициальный отдел. 1909. № 5. С. 162-169.

33. Воскресенский А. Покрово-Болдинский монастырь близ Астрахани (Историко-статистический очерк) // Астраханские Епархиальные Ведомости. Неофициальный отдел. 1909. № 7. С. 230-238.

34. Воскресенский А. Владикавказский Троицкий мужской монастырь // Владикавказские епархиальные ведомости. Неофициальная часть. 1908. №. 35. C. 634-640.

35. Воскресенский А. Монастырское подворье Второ-Афонской Успенской обители в г. Пятигорске // Владикавказские епархиальные ведомости. Неофициальная часть. 1908. № 31. С. 575-579.

36. Воскресенский А. Монастырское подворье Второ-Афонской Успенской обители в г. Пятигорске // Владикавказские епархиальные ведомости. Неофициальная часть. 1908. № 32. С. 589-596.

37. Воскресенский А. Второ-Афонское всенощное бдение // Владикавказские епархиальные ведомости. Неофициальная часть. 1908. № 29. С. 532-538. 
38. Воскресенский А. Черноморская Екатерино-Лебяжская Николаевская общежительная пустынь Кубанской области. Нижний Новгород: типо-лит. И. М. Машистова, 1909. 35 с.

39. Воскресенский А. Материалы для статистического описания церквей и монастырей Астраханской епархии // Астраханские епархиальные ведомости. Неофрициальный отдел. 1909. № 1. С. 5-11.

40. Воскресенский А. Город Елец в его настоящем и прошлом: (Опыт ист. очерка). Елец: Типография газеты «Голос порядка», 1911. 186 с.

41. Воскресенский А. Из летописи Павло-Обнорского монастыря: (посещение обители Великою Княгинею Елизаветою Феодоровною) // Прибавления к Вологодским епархиальным ведомостям. 1912. № 20. С. 497-501.

42. Воскресенский А. Свято-Троицкий Павло-Обнорский третьеклассный общежительный мужской монастырь Вологодской епархии: Исторический очерк. Вологда: Издательство монастыря, 1914. 224 с.

43. Воскресенский А. Троицко-Павло-Обнорский Патерик. Павло-Обнорский игумен Иоасаф, в схиме Серафим, ученик преподобного Серафима Саровского // Русский инок. 1915. № 21, вып. 134. С. 1299-1305.

44. Воскресенский А. Троицко-Павло-Обнорский Патерик. Павло-Обнорский иеромонах Нафанаил. Павло-Обнорского монастыря архимандрит Агафангел // Русский инок. 1915. № 24, вып. 137. С. 1415-1428.

45. Воскресенский А. Троицко-Павло-Обнорский Патерик. Павло-Обнорский старец - иеромонах Сергий // Русский инок. 1916. № 1, вып. 138. С. 41-45.

46. Государственный архив Тульской области. Ф. 3. Оп. 8. Д. 2452.

47. Служба преподобному отцу нашему Макарию Жһабынскому, Белевскому чудотворцу. М.: Синодальная Типография, 1915. 24 л.

48. Центральный архив Нижегородской области. Ф. 588. Оп. 1. Д. 416 а.

49. Ростовский филиал Государственного архива Ярославской области. Ф.145. Оп. 2. Д. 5.

50. Отдел рукописей Российской Государственной библиотеки. Ф. 765. К. 17. Д. 45.

51. Центральный Государственный архив Москвы. Ф. 2393. Оп. 1. Д. 3436. 